\title{
VYUŽITIE FOTOGRAMETRICKÉHO SKENOVANIA KULTÚRNEHO DEDIČSTVA PRE ÚČELY KATASTRA NEHNUTELNOSTÍ
}

\author{
USAGE OF PHOTOGRAMMETRIC SCANNING OF CULTURAL \\ HERITAGE FOR THE PURPOSES OF THE CADASTRE OF REAL ESTATE
}

\author{
Peter Kysel ${ }^{*}, 1$
}

*peter.kysel@stuba.sk

${ }^{1}$ Slovenská Technická Univerzita v Bratislave, Stavebná fakulta, Katedra geodézie, Radlinského 2766/11, 81005 Bratislava

\begin{abstract}
Abstrakt
Mapový fond katastra dnes obsahuje mapy rôzneho pôvodu a kvality, pričom v ňom prevažujú nekvalitné mapy. Je nutná jeho obnova, ktorá by mala byt' efektívna. Aby bol tento ciel' dosiahnutý, okrem špeciálnych meraní pre potreby nového mapovania bude možno potrebné využit' aj merania z iných zdrojov. Príspevok sa zaoberá testovaním využitel’nosti fotogrametrického zamerania kultúrneho dedičstva pre účely katastra. V rámci príspevku boli pomocou fotogrametrie určené súradnice bodov rohov budov a porovnané s existujúcou číselnou katastrálnou mapou. Na základe týchto výsledkov bola následne posúdená presnost' a využitel’nost' merania pre kataster. Toto a podobné merania by sa $\mathrm{v}$ budúcnosti mohli stat' vhodným doplnkom $\mathrm{k}$ novým meraniam, čím by sa mohol zrýchlit' a zefektívnit' celý proces mapovania.
\end{abstract}

\section{Kl’účové slová}

Obnova katastrálneho operátu, fotogrametria, UAV, kultúrne dedičstvo.

\begin{abstract}
The cadastral map collection contains maps of different origin and quality, and the less-quality maps are prevailing. Its effective renewal is needed. To meet this goal, it would be maybe necessary to use measurements from other sources besides the special measurements for the new mapping. The paper deals with the testing of exploitability of a photogrammetric measurement of cultural heritage for the cadastre. In the paper, the coordinates of building corners were determined using photogrammetry and compared to the existing numerical cadastral map. The precision and exploitability of the measurement for the cadastre was assessed based on these results. This and similar measurements could be suitable supplement for the measurements and could make the process of mapping more effective.
\end{abstract}

\section{Key words}

Cadastral operate renewal, photogrammetry, UAV, cultural heritage.

\section{1 ÚVOD}

V dnešnej dobe je vlastníctvo nehnutel'ností jednou z najdôležitejších tém v spoločnosti. Nehnutel’nosti totiž predstavujú pre ich vlastníkov určitú istotu. Pre chod spoločnosti je taktiež vel'mi dôležitou témou manažment pôdy. Podmienkou pre fungujúci systém manažmentu pôdy je komplexný a presný nástroj, akým je kataster nehnutel'ností. Z týchto dôvodov je potrebné, aby boli aj nehnutel'nosti v katastri evidované kvalitne a presne tak, aby zodpovedali dnešným náročným požiadavkám. Jedným z hlavných problémov katastra je kvalita jeho mapového fondu. Nachádzajú sa $\mathrm{v}$ ňom mapy rôzneho pôvodu a kvality a $\mathrm{v}$ žiadnom prípade sa nedá hovorit' o kvalitnom evidovaní nehnutel'ností. V súčasnosti je nutná jeho komplexná obnova, pričom táto obnova by mala byt’ zároveň rýchla, efektívna a nenákladná.

V̌̌etky katastrálne mapy sú už v súčasnosti spravované v digitálnej vektorovej forme, preto sa nazývajú vektorové katastrálne mapy (VKM). Z hl'adiska kvality ich delíme na číselné (VKMč) a nečíselné (VKMn). Najhoršou čast'ou sú práve nečíselné vektorové katastrálne mapy. História väššiny týchto máp siaha až do čias rakúsko-uhorskej monarchie. Body v týchto mapách neboli zamerané číselnými metódami, preto sa z merania 
zachoval iba grafický záznam mapy. Kvôli vlastnostiam použitých súradnicových systémov, kartografických zobrazení, metód merania a d’alším faktorom sú tieto grafické záznamy nepresné a nezodpovedajú dnešným požiadavkam na presnost'. Pri tomto druhu katastrálnych máp je teda nutná komplexná obnova v podobe nového katastrálneho mapovania. O niečo lepšia situácia je v oblasti číselných katastrálnych máp. Tieto boli vyhotovené v novšom období už pomocou číselných metód merania. To znamená, že z merania sa zachovali súradnice jednotlivých podrobných bodov v záväznom súradnicovom systéme S-JTSK, prípadne merané veličiny. Tieto mapy však tiež obsahujú určité chyby, ktoré znižujú kvalitu evidovania nehnutel'ností. Pri týchto mapách pravdepodobne nebude potrebná komplexná obnova pomocou nového mapovania, ale kvôli zvýšeniu kvality evidovania nehnutel'ností tu bude musiet' prebehnút' určitý druh obnovy.

V súčasnosti sa však pri meraniach v katastri nehnutel'ností používajú väčšinou iba "klasické" geodetické metódy, akými sú napríklad metóda GNSS alebo polárna metóda. Aby však bola obnova katastrálnych máp efektívna a nenákladná, tieto geodetické metódy už nemusia na dosiahnutie tohto ciel'a stačit'. Taktiež sme svedkami rozvoja katastrálnych systémov do tretej dimenzie. V trojrozmernom katastri nehnutel'ností už pravdepodobne "klasické" metódy nebudú poskytovat' dostatok informácií, preto bude potrebné využit' nové moderné metódy merania. Jednou z týchto metód môže byt' fotogrametria s využitím bezpilotných leteckých prostriedkov, tzv. UAV fotogrametria. Práve táto metóda môže poskytnút' všetky potrebné informácie, a zároveň môže byt’ aj dostatočne efektívna a nenákladná pre proces katastrálneho mapovania.

Aj meranie a spracovanie výsledkov pomocou UAV fotogrametrie však trvá určitý čas, preto musia byt' účelu prispôsobené aj parametre snímkového letu. Aby však bol celý proces obnovy katastrálnych máp ešte efektívnejší, môže sa v určitých prípadoch využit' aj fotogrametrické snímkovanie, ktoré bolo primárne vyhotovené pre iný účel. Ciel'om tohto príspevku je ukázat' využitel'nost' fotogrametrického skenovania kultúrneho dedičstva pomocou kombinácie UAV a pozemnej fotogrametrie pre účely katastrálneho mapovania, pričom hlavnou náplňou bude porovnanie dosiahnutých výsledkov s existujúcou katastrálnou mapou, čím bude dokázané, že presnost' tohto merania je pre tieto účely dostatočná.

\section{SÚČASNÝ STAV PROBLEMATIKY}

Mapový fond katastra nehnutel'ností v Slovenskej republike je v súčasnosti naplnený rôznymi typmi katastrálnych máp, ktoré majú rôzny pôvod a kvalitu. Kvalita týchto máp je daná spôsobom ich tvorby, použitým súradnicovým systémom, kartografickým zobrazením a spôsobom ich aktualizácie, prekresl'ovania, zosúvisl'ovania a transformácie [1]. V súčasnej dobe je nutná homogenizácia katastrálneho mapového diela, pretože jeho súčast’ou je vel'ké množstvo heterogénnych údajov.

Vektorové katastrálne mapy (VKM) sa podl’a súčasných predpisov delia na dve skupiny - VKM číselné (VKMč) a VKM nečíselné (VKMn). VKMč vznikli na podklade výsledkov meraní, ktoré boli vykonané číselnými metódami merania, najčastejšie polárnou alebo ortogonálnou metódou, prípadne metódou GNSS pri novších VKMč. Všetky body v týchto mapách majú určené presné súradnice v záväznom systéme S-JTSK a majú pridelený kód kvality $\mathrm{T}=1$ až $\mathrm{T}=4$ [2].

Hlavným problémom mapového fondu katastra nehnutel'ností sú VKM nečíselné. Tieto mapy majú dlhú históriu a pôvod najstarších siaha až do polovice 19. storočia. Tieto mapy boli sice vyhotovené pomocou merania, ale v tej dobe sa využívali takmer výlučne iba nečíselné metódy merania, čo znamená, že zo samotného merania sa nezachovali žiadne súradnice bodov ani záznamy meraných veličín, ale výsledkom bol iba grafický záznam mapy. Pôvodne boli vyhotovené v starých uhorských geodetických súradnicových systémoch, najčastejšie v stereografickom súradnicovom systéme. Počas doby svojej existencie boli viackrát upravované, prekresl'ované a zosúvisl'ované, pričom každý z týchto krokov iba znižoval celkovú kvalitu a presnost' mapy. Nakoniec boli naskenované, transformované do systému S-JTSK a vektorizované do dnešnej podoby VKMn. Transformácia medzi pôvodnými súradnicovými systémami a S-JTSK však nebola jednoznačná, preto je predpoklad, že polohová presnost' dnešných VKMn nie je lepšia ako 2 až $5 \mathrm{~m}$. Dnes sa VKMn podl'a spôsobu spravovania a uloženia novších číselných výsledkov meraní delia na dve podskupiny - VKM implementované (VKMi) a VKM transformované (VKMt). VKMi majú tieto číselné výsledky implementované priamo do pôvodnej nečíselnej VKM, preto môžu obsahovat' body so všetkými piatimi kódmi kvality. VKMt naopak obsahujú iba nečíselné body s kódom kvality $\mathrm{T}=5$ a všetky novšie číselné výsledky meraní sú zhromažd’ované v oddelenom súbore - súbore prevzatých meraní (SPM), ktorý však nepokrýva celé katastrálne územie, ale iba lokality, kde boli tieto novšie merania vykonané [2]. Podl’a oficiálnych údajov tvoria VKMn až približne polovicu mapového fondu katastra, preto je v súčasnosti nutná ich obnova.

V súčasnosti sú však požiadavky na čas a efektivitu obnovy katastrálnych máp vysoké, a zároveň je tu požiadavka minimalizácie nákladov na obnovu. V súčasnosti sú však pri katastrálnom mapovaní používané najmä klasické geodetické metódy, najmä metóda GNSS a jej kombinácia s polárnou metódou s využitím univerzálnych meracích staníc. Tieto metódy sa však v blízkej budúcnosti môžu stat' nepostačujúcimi. Okrem vysokých požiadavok na čas a náklady obnovy sme vo svedkami postupného rozvoja katastrálnych systémov 
vo svete do tretieho rozmeru. Preto je pri katastrálnych meraniach potrebné využit’ nové a moderné technológie, ktoré by zefektívnili celý proces pri minimalizácii nákladov, a zároveň by poskytovali dostatočné množstvo informácií, ktoré by v budúcnosti mohli byt' využité aj v rámci trojrozmerného katastra nehnutel'ností. Jednou z týchto metód môže byt' práve jedna z druhov fotogrametrie - fotogrametria s využitím bezpilotných leteckých prostriedkov, nazývaná aj UAV fotogrametria.

Technológia fotogrametrie nie je v oblasti katastra nehnutel'ností žiadnou novinkou a bola predmetom viacerých domácich aj zahraničných publikácií [3], [4]. V minulosti sa však jednalo o "klasickú" leteckú fotogrametriu, ktorá bola vhodnejšia skôr pre tvorbu topografických máp. V posledných rokoch sa však stala fotogrametria opät' témou v oblasti katastra nehnutel'ností, a to najmä vd'aka rozvoju nových technológií. Niektorí vedci sa sústred'ujú na meranie hraníc katastrálnych parciel z fotogrametrických máp vel'kých mierok, ortorektifikovaných snímok alebo družicových snímok s vysokým rozlíšením [5]. Vel'kou oblast'ou výskumu je však práve UAV fotogrametria. Táto metóda umožňuje snímkovanie z menšej letovej výšky ako pri "klasickej" leteckej fotogrametrii, čím vie zachytit' viac detailov. Polohu objektov je teda možné určit' s presnost'ou dostatočnou pre účely katastra. Táto technológia bola predmetom viacerých zahraničných publikácií, pričom boli skúmané možnosti jej využitia v katastri, bola testovaná presnost’ metódy pri katastrálnych meraniach, a dokonca bola testovaná možnost' automatického merania hraníc parciel na snímkach vyhotovených pomocou UAV [7],[8], [9]. Taktiež boli vyzdvihnuté d’alšie doplnkové výsledky tejto metódy, ktoré môžu byt' využité v iných oblastiach [8]. V Slovenskej republike bol zatial' publikovaný jeden príspevok, ktorý sa týkal zamerania rybníka pomocou UAV fotogrametrie pre účely tvorby geometrického plánu, pričom v štátnej správe doposial' neboli konkrétne skúsenosti s touto metódou. Výsledky boli vyhodnotené ako dostatočne presné pre účely katastra, a zároveň boli taktiež vyzdvihnuté aj doplnkové výsledky, ako napríklad detailná ortofotomozaika, digitálny výškový model alebo 3D model územia [10].

Tento snímkový nálet bol však vyhotovený špeciálne pre potreby katastra, čomu boli prispôsobené aj jeho parametre. Aby však bola obnova katastrálneho mapového fondu čo najefektívnejšia, je potrebné hl'adat' zdroje meraní aj v iných oblastiach. Jednou z týchto oblastí by mohlo byt' fotogrametrické skenovanie kultúrneho dedičstva. Ciel'om tohto príspevku je demonštrácia možnosti využitia jedného z týchto meraní, ktoré bolo vyhotovené v katastrálnom území Banská Štiavnica. Pôvodným účelom tohto merania bolo vyhotovenie rozvinutých pohl'adov uličných pásov. V rámci príspevku bude testované, či môže byt’ aj fotogrametrické zameranie tohto druhu využité pre potreby katastrálneho mapovania.

\section{METODIKA}

Snímkovanie bolo vykonané v katastrálnom území Banská Štiavnica v lokalite Radničného námestia, Ul. Andreja Kmet’a a Kammerhofskej ulice. Pre účely tohto príspevku bola vybraná lokalita hornej časti Radničného námestia od domu so s.č. 107 po stavbu so s.č. 45 (Obr. 1.). Hlavným účelom tohto snímkovania bolo vyhotovenie rozvinutých pohl'adov uličných pásov.

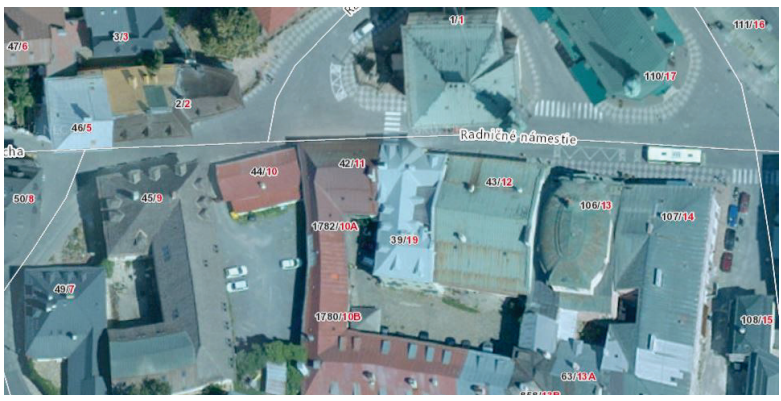

Obr. 1 Lokalita snímkovania [zdroj: MK ZBGIS].

Snímkovanie bolo vykonané kombináciou metód pozemnej a UAV fotogrametrie. Snímky boli vyhotovené v pásoch rovnobežných $\mathrm{s}$ fasádou, pričom väčšina snímok bola vyhotovená vo vodorovnej polohe kamery. Na nasnímkovanie striech boli využité šikmé snímky so sklonom kamery približne $30^{\circ}$. Pozdížny prekryt medzi snímkami bol približne 70-80\% a priečny prekryt medzi pásmi približne 50-60\%. Fasáda bola snímkovaná zo vzdialenosti približne $20 \mathrm{~m}$, čomu zodpovedá vel'kost' pixela na objekte približne $3 \mathrm{~mm}$.

Spodná čast' fasád bola nasnímkovaná pomocou metódy pozemnej fotogrametrie s využitím kamery Nikon D7500 (Obr. 2. , vl'avo) s objektívom s 20 mm ohniskovou vzdialenost'ou. Kamera je vybavená CMOS snímačom 
s 20,9 MP rozlíšením. Horná čast’ fasád vrátane striech bola nasnímkovaná pomocou UAV DJI Air 2S (Obr. 2. , vpravo). Tento dron je vybavený kamerou s 1" CMOS snímačom s rozlíšením 20 MP. Kamera je stabilizovaná 3osovým gimbalom a dron je taktiež vybavený GNSS prijímačom a systémom na vyhýbanie sa prekážkam. Jeho hmotnost' je $595 \mathrm{~g}$, teda let s ním je takmer bez obmedzení aj v oblasti intravilánu.
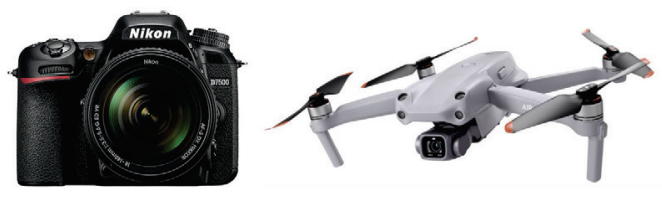

Obr. 2 Prístroje použité na snímkovanie - Nikon D7500 (vl'avo) a DJI Air 2S (vpravo) [zdroje: www.nikon.sk, www.dji.com].

Zavlícovanie do záväzného súradnicového systému S-JTSK bolo vykonané pomocou 12 vlícovacích bodov. Vlícovacie body boli zamerané priestorovou polárnou metódou prístrojom Leica TC805, pričom stanoviská prístroja boli určené metódou GNSS-RTK s pripojením na siet’ SKPOS pomocou prístroja Trimble R2. Konfigurácia vlícovacích bodov sa nachádza na Obr. 3. Vlícovacie body boli signalizované prirodzeným spôsobom ako význačné body na fasáde jednotlivých stavieb (napr. rohy okien).

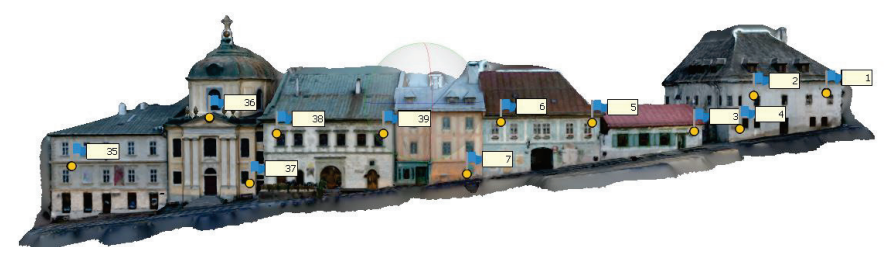

Obr. 3 Konfigurácia vlícovacích bodov na 3D modeli územia [spracoval autor].

Spracovanie snímok bolo vykonané v softvéri Agisoft Metashape metódou Structure-from-Motion, resp. fotogrametrického skenovania. Kamery neboli kalibrované a na určenie prvkov vnútornej orientácie bola použitá metóda samokalibrácie. Prvým krokom bola orientácia snímok, ktorej výsledkom bolo riedke mračno bodov. Následne bolo vykonané zavlícovanie pomocou označenia vlícovacích bodov na snímkach a priestorovej podobnostnej transformácie do systému S-JTSK. Ďalšími krokmi bolo generovanie hustého mračna bodov a nakoniec 3D modelu [11]. Výsledný rozvinutý pohl'ad bol vytvorený kombináciou ortofotomozaík, ktoré boli vygenerované zvlášt' pre každú stavbu.

Nakoniec boli v softvéri Agisoft Metashape určené súradnice bodov význačných pre kataster nehnutel'ností, v tomto prípade rohov jednotlivých budov. Súradnice týchto bodov boli určené pomocou ich identifikácie a označenia na niekol'kých snímkach, pričom softvér na základe parametrov ich orientácie vypočítal polohu týchto bodov v S-JTSK. Na posúdenie vhodnosti týchto výsledkov pre kataster nehnutel'ností boli súradnice určené pomocou fotogrametrie porovnané so súradnicami zodpovedajúcich bodov v existujúcej číselnej VKM, pričom na polohové odchýlky boli aplikované kritériá podl'a Vyhlášky č. 461/2009. Pre body s kódom kvality T $=3$ teda platí, že polohová odchýlka nesmie prekročit' hodnotu $0,24 \mathrm{~m}$.

\section{VÝSLEDKY A DISKUSIA}

Meranie a spracovanie bolo vykonané v dňoch 12.9.-19.9.2021 v katastrálnom území Banská Štiavnica. Ako testovacia lokalita bol zvolený uličný pás na Radničnom námestí. Bolo vyhotovených 265 pozemných snímok pomocou kamery Nikon D7500 a 290 snímok pomocou UAV DJI Air 2S. Zavlícovanie do S-JTSK bolo vykonané pomocou 12 vlícovacích bodov zameraných s pripojením na siet' SKPOS. Fotogrametrické spracovanie bolo vykonané metódou Structure-from-Motion v softvéri Agisoft Metashape. Po vytvorení 3D modelu územia boli v rovnakom softvéri určené súradnice bodov pre účely katastra pomocou ich identifikácie na viacerých snímkach, pričom softvér následne na základe parametrov orientácie určil ich súradnice. Týmto spôsobom bolo určených 15 bodov, ktoré sú význačné pre kataster nehnutel’ností ( $\mathrm{v}$ tomto prípade najmä rohov budov), ktorých konfigurácia na podklade VKM je zobrazená na Obr. 4. Následne boli tieto súradnice exportované do formátu TXT a v softvéri Kokeš boli vypočítané polohové odchýlky $\Delta$ p medzi nimi a príslušnými bodmi v existujúcej 
VKMč. Nakoniec bola na posúdenie presnosti vypočítaná priemerná hodnota polohových odchýlok a hodnota RMSE. Výsledky sú uvedené v Tab. 1. V tejto tabul'ke sú taktiež uvedené aj čísla bodov podl'a VKM a ich kódy kvality T.

Tab. 1 Polohové odchýlky medzi bodmi určenými fotogrametricky a bodmi v súčasnej VKMč.

\begin{tabular}{ccc}
\hline Číslo bodu & $\boldsymbol{\Delta p}[\mathbf{m}]$ & $\mathbf{T}$ \\
\hline 3901440031 & 0,12 & 3 \\
3901440032 & 0,03 & 3 \\
3901440241 & 0,06 & 3 \\
3901440243 & 0,06 & 3 \\
3901440240 & 0,06 & 3 \\
3901440034 & 0,05 & 3 \\
3901440035 & 0,04 & 3 \\
3901440255 & 0,03 & 3 \\
3901440037 & 0,06 & 3 \\
3915000001 & 0,07 & 3 \\
3901440234 & 0,06 & 3 \\
3901440233 & 0,06 & 3 \\
3901440078 & 0,04 & 3 \\
3901440077 & 0,09 & 3 \\
3901440141 & 0,04 & 3 \\
\hline Priemer [m] & 0,058 & - \\
RMSE [m] & 0,062 & - \\
\hline
\end{tabular}

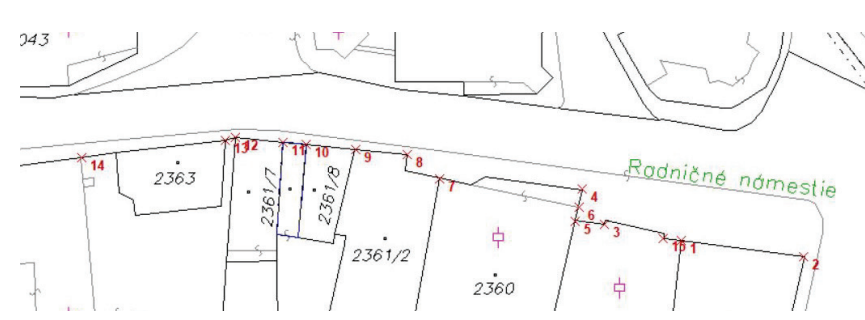

Obr. 4 Konfigurácia určovaných bodov na podklade existujúcej VKMč [spracoval autor].

Maximálna hodnota polohových odchýlok medzi bodmi určenými pomocou fotogrametrie a bodmi v existujúcej VKMč bola $0,12 \mathrm{~m}$. Väčšina hodnôt sa pohybovala na úrovni $0,06 \mathrm{~m}$, o čom hovorí aj ich priemer, ktorého hodnota je $0,058 \mathrm{~m}$. Hodnota RMSE bola taktiež na úrovni približne $0,06 \mathrm{~m}$. Všetky kontrolné body mali vo VKMč pridelený kód kvality $\mathrm{T}=3$, čo znamená, že maximálna dovolená polohová odchýlka má podl’a súčasných predpisov hodnotu $0,24 \mathrm{~m}$ pre body s týmto kódom kvality. Ked’že maximálna hodnota bola $0,12 \mathrm{~m}$, na všetkých bodoch bola táto podmienka splnená. Tieto výsledky sú uspokojivé a presnost' tohoto merania pomocou kombinácie pozemnej a UAV fotogrametrie môže byt’ posúdená ako dostatočná pre účely katastra nehnutel'ností. Tento fakt podporuje aj hodnota RMSE.

Pre tento účel by bolo pravdepodobne korektnejšie porovnanie súradníc určených pomocou fotogrametrie s novým meraním vykonaným pomocou geodetických metód používaných v súčasnosti (polárna metóda, metóda GNSS). Meranie však pôvodne nebolo určené pre účely katastra nehnutel'ností a o tomto využití sa rozhodlo až neskôr, preto v teréne nebolo vykonané zameranie rohov budov polárnou metódou. Bolo rozhodnuté o porovnaní s existujúcou VKMč. Pôvodné katastrálne mapovanie tu bolo ukončené v roku 1988, teda meranie bolo vykonané terestrickými metódami s pripojením na existujúcu siet’ geodetických základov. Toto meranie zväčša nedosahovalo takú presnost' ako dnešné geodetické metódy, a taktiež pri meraní niekedy dochádzalo ku generalizácii niektorých prvkov budov, preto môžu dosahovat' niektoré polohové odchýlky väčšie hodnoty.

Aj napriek tomu však bolo dokázané, že toto meranie, ktoré bolo pôvodne vykonané pre účely dokumentácie kultúrneho dedičstva, je možné použit' aj pre účely katastra nehnutel'ností. Tento fakt by mohol v budúcnosti v niektorých oblastiach výrazne zrýchlit' celý proces katastrálneho mapovania, kedy by sa mohli využit' všetky dostupné podklady tohto druhu, pričom tieto územia by sa už znovu nemapovali. Identifikácia bodov prebieha priamo na snímkach bez potreby ich identifikácie $\mathrm{v}$ teréne. Nepredpokladá sa, že by bolo pri tejto metóde potrebné domeriavanie terestrickými metódami, ked’že pri použitom spôsobe snímkovania sú na snímkach viditel’né všetky 
body, ktoré by boli viditel'né aj v teréne. Týmto by sa dal ušetrit' čas aj náklady vynaložené na mapovanie. Výhodou sú taktiež aj d’alšie výsledky tohto merania, ako napríklad 3D model územia. Homogenita výslednej katastrálnej mapy pri použití meraní z rôznych zdrojov by mala byt' zabezpečená využitím rovnakých geodetických základov - permanentnej siete SKPOS.

\section{ZÁVER}

Príspevok sa zaoberá využitím rôznych fotogrametrických meraní pre účely katastra nehnutel'ností. Katastrálny mapový fond totiž obsahuje vel'a nepresných a nekvalitných máp a jedinou cestou na zlepšenie tohto stavu je jeho obnova. Táto obnova by však zároveň mala byt' rýchla, nenákladná a efektívna, preto bude v budúcnosti nutné nájst' nové metódy merania, ktoré by tieto podmienky spíňali. Jednou z týchto metód môže byt' aj UAV fotogrametria. Viaceré štúdie o presnosti a výhodách tejto metódy pri použití v katastri už boli publikované. Při procese nového mapovania však nie je nutné využívat' iba špeciálne snímkové lety, ktoré boli vykonané na tento účel, ale aj iné snímkovania, ktoré boli pôvodne určené na iné účely. Tento príspevok sa zaoberá práve touto možnost'ou, pričom je testovaná využitel'nost' fotogrametrického skenovania kultúrneho dedičstva pre účely katastra. Snímkovanie bolo vykonané v katastrálnom území Banská Štiavnica kombináciou pozemnej a UAV fotogrametrie, pričom ako testovacia lokalita bola zvolená čast’ Radničného námestia. Po spracovaní snímok boli určené súradnice bodov charakteristických pre kataster ( $\mathrm{v}$ tomto prípade rohov budov) a boli porovnané so súradnicami príslušných bodov $\mathrm{v}$ existujúcej VKMč. Polohové odchýlky na všetkých bodoch spĺn̆ali podmienky, teda presnost' tohto merania bola vyhodnotená ako dostatočná pre účely katastra. Meranie by teda bolo využitel'né pri novom mapovaní a d'alšie merania v tejto lokalite by už nemuseli byt' vykonané. Plným využitím tohto a d'alších podobných meraní by sa $\mathrm{v}$ budúcnosti mohlo dosiahnut celkové zrýchlenie a zefektívnenie procesu nového mapovania, čím by sa v konečnom dôsledku šetrili aj vynaložené náklady.

\section{Pod'akovanie}

Tento príspevok bol vypracovaný s podporou Ministerstva školstva, vedy, výskumu a športu Slovenskej Republiky v rámci Vedeckej grantovej agentúry, č. projektu VEGA 1/0584/19.

\section{Použité zdroje}

[1] Horňanský, I., Leitman, M., Ondrejička, E. „Na ceste k homogenizácii katastrálneho mapového diela.“ Geodetický a kartografický obzor 60/102, 2014, s. 229-240. ISSN 1805-7446.

[2] Vyhláška ÚGKK SR č. 461/2009 Z. z., ktorou sa vykonáva zákon č. 162/1995 Z. z. o katastri nehnutel'ností a o zápise vlastníckych a iných práv k nehnutel'nostiam (katastrálny zákon) v znení neskorších predpisov.

[3] Horňanský, I., Ondrejička, E., Šuppová, I., „Obnova mapového fondu od roku 1964 po súčasnost'.“ Zborník prednášok z 11. medzinárodnej konferencie o katastri nehnutel’ností, pp. 18-35, ČastáPapiernička, 2014.

[4] Weismann, K., „Photogrammetry applied to cadastral survey in Switzerland.“ The Photogrammetric Record, Vol. 7(37), s. 5-15, 1971.

[5] Šafář, V., et al., „Analýza možnosti integrace nových technologií do procesu obnovy katastrálního operátu novým mapováním." Geodetický a kartografický obzor, Vol. 61/103, 2015, s. 49-53. ISSN 1805-7446.

[6] Housarová, E., Šedina, J., Pavelka, K., „RPAS in Cadastral Applications.“ 16th International Multidisciplinary Scientific GeoConference SGEM 2016 Conference Proceedings, Book 2 Vol. 2, s. 987-994, 2016.

[7] Fetai, B., et al., „Extraction of Visible Boundaries for Cadastral Mapping Based on UAV Imagery.“ Remote Sensing, Vol. 11, s. 1510, 2019.

[8] Manyoky, M., et al., „Unmanned Aerial Vehicle in Cadastral Applications.“ International Archives of the Photogrammetry, Remote Sensing and Spatial Information Sciences, Volume XXXVIII-1/C22, s. 5762, 2011.

[9] Chio, S., Chiang, Ch., „Feasibility Study Using UAV Aerial Photogrammetry for a Boundary Verification Survey of a Digitalized Cadastral Area in an Urban City of Taiwan." Remote Sensing, Vol. 12, s. $1682,2020$.

[10] Kysel', P., Hudecová, L. „Cadastral survey of a Fishpond Using UAV Photogrammetry.“ FIG e-Working Week 2021: Smart Surveyors for Land and Water Management - Challenges in a New Reality. Copenhagen: International Federation of Surveyors FIG, 2021. ISBN 978-87-92853-65-3.

[11] Agisoft Metashape User Manual: Professional Edition, Version 1.5, Agisoft LLC, 2019. 